\title{
Correction to: CXCL9 secreted by tumor- associated dendritic cells up-regulates PD- L1 expression in bladder cancer cells by activating the CXCR3 signaling
}

Weigang $\mathrm{Xiu}^{1,2,3}$ and Jingjing LuO ${ }^{1,2^{*}}$

\section{Correction to: BMC Immunol (2021) 22:3 \\ https://doi.org/10.1186/s12865-020-00396-3}

It was highlighted that the original article [1] contained errors in the authors affiliations. This Correction article shows the incorrect and correct author affiliations. The original article has been updated.

\section{Incorrect}

Weigang $\mathrm{Xiu}^{1}$ and Jingjing $\mathrm{Luo}^{2,3}$

1 Department of Thoracic Oncology and State Key Laboratory of Biotherapy, Cancer Center, West China Hospital, Sichuan University, Chengdu 610041, PR China. 2 Department of Laboratory Medicine, West China Second University Hospital, Sichuan University, Chengdu 610041, PR China. 3 Key Laboratory of Birth Defects and Related Diseases of Women and Children (Sichuan University), Ministry of Education, Chengdu 610041, PR China.

\section{Correct}

Weigang $\mathrm{Xiu}^{1,2,3}$ and Jingjing Luo ${ }^{1,2}$

1 Department of Laboratory Medicine, West China Second University Hospital, Sichuan University. 2 Key Laboratory of Birth Defects and Related Diseases of Women and Children (Sichuan University), Ministry of
Education. 3 Department of Thoracic Oncology and State Key Laboratory of Biotherapy, Cancer Center, West China Hospital, Sichuan University, Chengdu 610041, PR China.

\begin{abstract}
Author details
'Department of Laboratory Medicine, West China Second University Hospital, Sichuan University, Chengdu 610041, PR China. ${ }^{2}$ Key Laboratory of Birth Defects and Related Diseases of Women and Children (Sichuan University), Ministry of Education, Chengdu 610041, PR China. ${ }^{3}$ Department of Thoracic Oncology and State Key Laboratory of Biotherapy, Cancer Center, West China Hospital, Sichuan University, Chengdu 610041, PR China.
\end{abstract}

Published online: 25 February 2021

\section{Reference}

1. Xiu W, Luo J. CXCL9 secreted by tumor-associated dendritic cells upregulates PD-L1 expression in bladder cancer cells by activating the CXCR3 signaling. BMC Immunol. 2021;22:3. https://doi.org/10.1186/s12 865-020-00396-3.

\footnotetext{
The original article can be found online at https://doi.org/10.1186/s12865020-00396-3.

* Correspondence: ljjloveningning@163.com

'Department of Laboratory Medicine, West China Second University Hospital, Sichuan University, Chengdu 610041, PR China

${ }^{2}$ Key Laboratory of Birth Defects and Related Diseases of Women and Children (Sichuan University), Ministry of Education, Chengdu 610041, PR China

Full list of author information is available at the end of the article
}

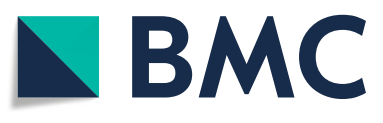

(c) The Author(s). 2021 Open Access This article is licensed under a Creative Commons Attribution 4.0 International License, which permits use, sharing, adaptation, distribution and reproduction in any medium or format, as long as you give appropriate credit to the original author(s) and the source, provide a link to the Creative Commons licence, and indicate if changes were made. The images or other third party material in this article are included in the article's Creative Commons licence, unless indicated otherwise in a credit line to the material. If material is not included in the article's Creative Commons licence and your intended use is not permitted by statutory regulation or exceeds the permitted use, you will need to obtain permission directly from the copyright holder. To view a copy of this licence, visit http://creativecommons.org/licenses/by/4.0/ The Creative Commons Public Domain Dedication waiver (http://creativecommons.org/publicdomain/zero/1.0/) applies to the data made available in this article, unless otherwise stated in a credit line to the data. 